\title{
Crystalline Rocks of the
}

Potomac River Gorge

Near Washington, D.C.

GEOLOGICAL SURVEY PROFESSIONAL PAPER 414-H

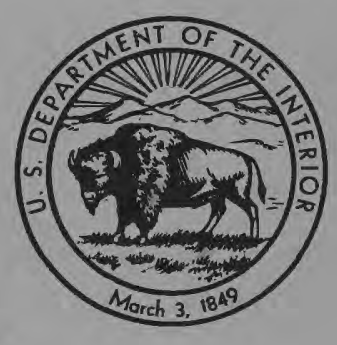




\section{Crystalline Rocks of the}

\section{Potomac River Gorge}

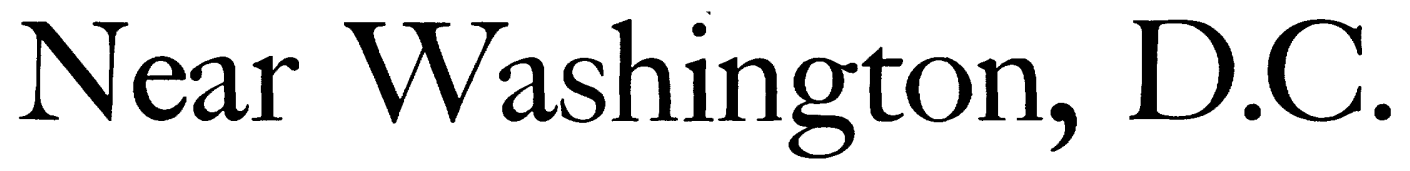

By JOHN C. REED, JR., and JANICE JOLLY

CONTRIBUTIONS TO GENERAL. GEOLOGY

GEOLOGICAL SURVEY PROFESSIONAL PAPER 414-H

$A$ description of the rocks exposed in the gorge of the Potomac River below Great Falls, with a discussion of their structural and metamorphic history

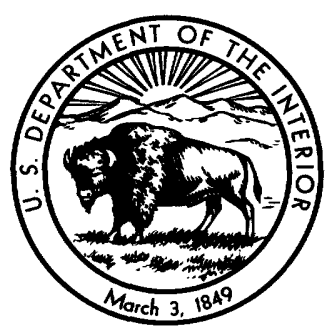




\section{UNITED STATES DEPARTMENT OF THE INTERIOR \\ STEWART L. UDALL, Secretary \\ GEOLOGIGAL SURVEY \\ Thomas B. Nolan, Director}

For sale by the Superintendent of Documents, U.S. Government Printing Office

Washington D.C. 20402 


\section{CONTENTS}

Abstract.-.

Introduction

Geologic setting and general features.

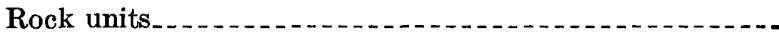

Schist and quartzite........

Amphibolite

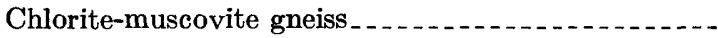

Granitic rocks . ......

Pegmatites and veins........... Structure

Bedding and bedding foliation $\left(S_{1}\right) \ldots \ldots$

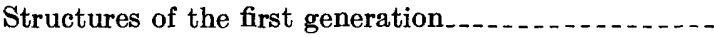

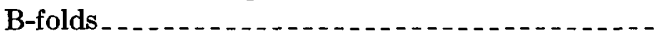

Cleavage $\left(S_{2}\right)$

Lineation $\left(L_{1}\right)$
Page

H1

1

1

2

2
Structure-Continued

Structures of the second generation

Cleavage $\left(S_{3}\right)$

Lineation $\left(L_{2}\right) \ldots \ldots \ldots$

Geometry of the structures.

$S_{1-\ldots}$

$S_{2}$ and $L_{1 \ldots}$

$S_{3}$ and $L_{2}$

Relation of structural episodes to metamorphic

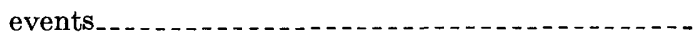

Summary of structural and metamorphic history

References cited
Page

H11

11

12

12

14

14

14

14

15

15

\section{ILLUSTRATIONS}

[Plates are in pocket]

Plate 1. Map of rock types in the Washington area, showing location of the area studied.

2. Geologic map and sections of part of the Potomac River Gorge near Washington, D.C.

Figure 1. Textures and structures of quartzite, schist, and migmatite

2. Distribution of discordant granitic bodies, pegmatite bodies, quartz veins, and selected metamorphic minerals _ -

3. Micrograph of albite replacement of microcline and older plagioclase

4. Micrograph of sillimanite replacement of biotite in schist

5. Micrograph of garnet in schist

6. Micrograph of cordierite in schist

7. Sketch of spotted quartzite

8. Sketch of breccia of angular amphibolite blocks in matrix of white inequigranular granodiorite

9. Textures and structures of chlorite-muscovite gneiss

10. Micrograph of plagioclase porphyroclast in gneiss

11. Sketch of inclusion of quartzite and schist in granitic body

12. Sketch of irregular dike of fine even-grained granodiorite in schist

13. Sketches of typical $B$-folds

14. Sketch of $B^{\prime}$-folds superimposed on $B$-folds in migmatitic schist and quartzite

15. Statistical diagrams showing orientation of structures

Page

\section{TABLE}





\title{
CONTRIBUTIONS TO GENERAL GEOLOGY
}

\section{GRYSTALLINE ROGKS OF THE POTOMAG RIVER GORGE NEAR WASHINGTON, D.C.}

\author{
By John C. Reed, JR., and JANice JoLLY
}

\begin{abstract}
Rocks of the Piedmont Plateau exposed in part of the gorge of the Potomac River near Great Falls are schist and quartzite of early Paleozoic(?) age, coarse-grained amphibolite in small silllike bodies, chlorite-muscovite gneiss in a large concordant body, and granitic rocks ranging in composition from quartz diorite to quartz monzonite in dikes and small discordant plugs.

The first episode of folding occurred during regional metamorphism which reached a climax in the central part of the area; there the schist and quartzite contain sillimanite, and migmatitic rocks are widespread.

Discordant granitic rocks are most common in the area of highest grade regional metamorphism, and field and petrographic evidence suggests that the granitic rocks may have been produced by mobilization of the silicic components of the country rocks with little or no introduction of material. Emplacement of the granitic bodies occurred largely after the major episode of folding and formation of the regional schistosity.

The chlorite-muscovite gneiss (Sykesville Formation of Cloos and Cooke, 1953) apparently formed through granulation, flowage and recrystallization of enclosing schist, without appreciable addition or subtraction of material.

All the rocks in the area have been affected by retrogressive metamorphism, which was most pervasive in the eastern part of the area. Earlier medium- and high-grade mineral assemblages were recrystallized, new lineations were formed, and older structures were deformed or destroyed.
\end{abstract}

\section{INTRODUCTION}

Below Great Falls, about 8 miles west of Washington, D.C., the Potomac River is incised in a spectacular gorge, which displays unexcelled exposures of the rocks of the Piedmont Plateau. This paper discusses the crystalline rocks exposed between Great Falls and Stubblefield Falls, about 3.5 miles downstream (pl. 1).

Keith (in Darton and Keith, 1901) made the first systematic study of the crystalline rocks of the Washington quadrangles. Cloos and Anderson (1950) studied part of Bear Island, Md., about 1 mile downstream from Great Falls, and Cloos (Cloos and Cooke, 1953) mapped the crystalline rocks of Montgomery County, Md. Bennison and Milton (1954) mapped adjacent parts of Fairfax County, Va.
The map and most of the field observations in this paper are by Reed; most of the petrographic parts of the paper are by Jolly.

\section{GEOLOGIC SETTING AND GENERAL FEATURES}

The structure of most areas of the Piedmont is difficult to decipher because of scarcity of exposures and marker horizons and the complexity of structural and metamorphic history. The exposures in the Potomac Gorge furnish an uncommon opportunity to relate the structural and metamorphic histories of the rocks.

In the Potomac Gorge a bedded sequence of mica schist and quartzite of early Paleozoic(?) age (mapped as Wissahickon Formation by Cloos and Cooke, 1953) with interlayered sill-like bodies of amphibolite is exposed in a complex series of nearly isoclinal folds (pl.2). Cleavage related to these folds dips steeply east in the western part of the area, vertically in the central part, and steeply to moderately west in the eastern part, forming a symmetrical fan.

At least two episodes of regional metamorphism have affected the rocks in the area. The earliest of these reached a maximum intensity in the central part of the area, where the schist and quartzite contain sillimanite and where migmatites were produced and dikes and small plugs of granitic rocks were emplaced. The major isoclinal folds and the prominent cleavage were produced during this event. The schistose chlorite-muscovite gneiss (Sykesville Formation of Cloos and Cooke, 1953) that crops out in the eastern part of the area may have been formed at this time. The grade of the earliest regional metamorphism decreases in the northwestern part of the area, where migmatites are absent and granitic rocks are rare, and where sillimanite and potassium feldspar are lacking in the schist. The decrease in metamorphic grade continues into northwestern Montgomery County, where Cloos' mapping (Cloos and Cooke, 1953) shows that the schist and quartzite pass into rocks of lower metamorphic grade surrounding Sugarloaf Mountain (pl. 1). 
Effects of a later episode of low-grade regional metamorphism and hydrothermal alteration have been superimposed on all the medium- and high-grade rocks of the area. Retrogression has been incomplete in the northwestern and central parts, but in the eastern part older minerals have been entirely converted to assemblages of the greenschist facies and older fabrics have been largely obliterated. A northwest- or west-plunging mineral lineation on the older cleavage was developed during this episode. This lineation is conspicuous throughout eastern Montgomery County, where 'Cloos (Cloos and Cooke, 1953) mapped large areas of oligoclase-muscovite schist, suggesting that the grade of the second regional metamorphism may increase eastward.

\section{ROCK UNITS}

\section{SCHIST AND QUARTZITE}

The rocks assigned to the Wissahickon Formation in the Potomac Gorge by Cloos (Cloos and Cooke, 1953) comprise a variety of muscovite-biotite, muscovitechlorite, and sericite-chlorite schists that are interlayered with quartzite and amphibolite schist, chloriteepidote schist, and sparse calc-silicate rocks.

Schist and quartzite are interlayered in all proportions. Beds range in thickness from less than an inch to more than 25 feet and are separated by schist layers fractions of an inch to a few tens of feet thick (fig. 1). Some of the quartzite layers display crossbedding, marked by dark micaceous partings; and a few beds 6 inches to 4 feet thick display conspicuous graded bedding, passing upward from medium-grained pebbly quartzite through finer grained quartzite and quartz schist into mica schist. Parts of the sequence consist of quartzite and schist in regular alternate layers, 4 to 8 inches thick, which Cloos and Anderson (1950) have described as "rhythmite." On the geologic map (pl. 2) areas in which quartzite forms 20 percent or more of the sequence are distinguished from areas in which quartzite is less abundant.

The mica schist is a medium- to fine-grained strongly foliated bluish- to greenish-gray rock composed predominantly of quartz, plagioclase, muscovite, biotite, and chlorite. Where the schist is of medium or high metamorphic grade and has not been thoroughly retrogressively metamorphosed, sillimanite, kyanite, garnet, and potassium feldspar are identifiable in hand specimens, and aggregates of sericite replacing aluminumsilicate minerals are common locally. Where retrogressive metamorphism has been more complete, the rock is a lustrous fine-grained chlorite-sericite schist, commonly containing pods and knots of quartz that stand out as nubbins on weathered surfaces.
The schist commonly displays two foliations; a highly contorted bedding foliation and cleavage parallel to axial planes of minor folds, which transects the bedding foliation. Both are marked by parallel alinement of micaceous minerals. In the retrogressively metamorphosed rocks east of the Anglers Inn syncline (pl. 2), the bedding foliation is completely obliterated, or remains only as scattered isoclinal hinges between the younger cleavage planes.

In the area of highest grade regional metamorphism and migmatization in the Bear Island syncline, the schist is' seamed and veined by light-colored quartzfeldspar laminae along both bedding foliation and cleavage, so that the outcrop has a "shredded" appearance (fig $1 B$ ). Locally the schist passes into migmatitic gneiss with foliation marked by dark micaceous wisps and discontinuous flow-disrupted layers of quartzite.

Quartz generally constitutes 20 to 40 percent of the schist, and plagioclase 5 to 25 percent. Unaltered plagioclase in the medium- and high-grade schist in the central and northwestern part of the area is oligoclase or andesine. Many grains are untwinned, but some display multiple albite and pericline twinning. Both normal and reverse zoning are common, and as many as four zones occur in some grains. Albite occurs as clear rims on more calcic plagioclase, as patches and intergrowths in other feldspars, and as cloudy grains containing inclusions of epidote, sericite, and other minerals, probably pseudomorphs after earlier, more calcic plagioclase. In the retrogressively metamorphosed rocks in the eastern part of the area, plagioclase is less abundant and is entirely clear granoblastic albite.

Microcline occurs in the schist in the area of highest grade regional metamorphism, and locally as scattered porphyroclasts in the retrogressively metamorphosed schist to the east (fig. 2). It rarely composes more than 1 percent of the rock. It occurs in cloudy sieve-textured" grains containing inclusions of biotite, quartz, and calcic plagioclase, and as clear irregular grains interstitial to these minerals. Microcline grains are rimmed and partly replaced by albite (fig. 3 ), and myrmekite is common between microcline and albite grains.

Muscovite and sericite compose 15 to 40 percent of most of the schist. Muscovite occurs as deformed flakes and aggregates parallel to the contorted bedding foliation and as smaller flakes parallel to cleavage in the less thoroughly retrogressively metamorphosed rocks. In the more thoroughly retrogressively metamorphosed schist, sericite occurs in folia parallel to cleavage and as aggregates replacing older minerals.

Biotite and chlorite form 10 to 30 percent of most of the schist. Biotite is predominant in the medium- and high-grade rocks that have been least affected by retro- 
CRYSTALLINE ROCKS, POTOMAC RIVER GORGE, NEAR WASHINGTON, D.C.
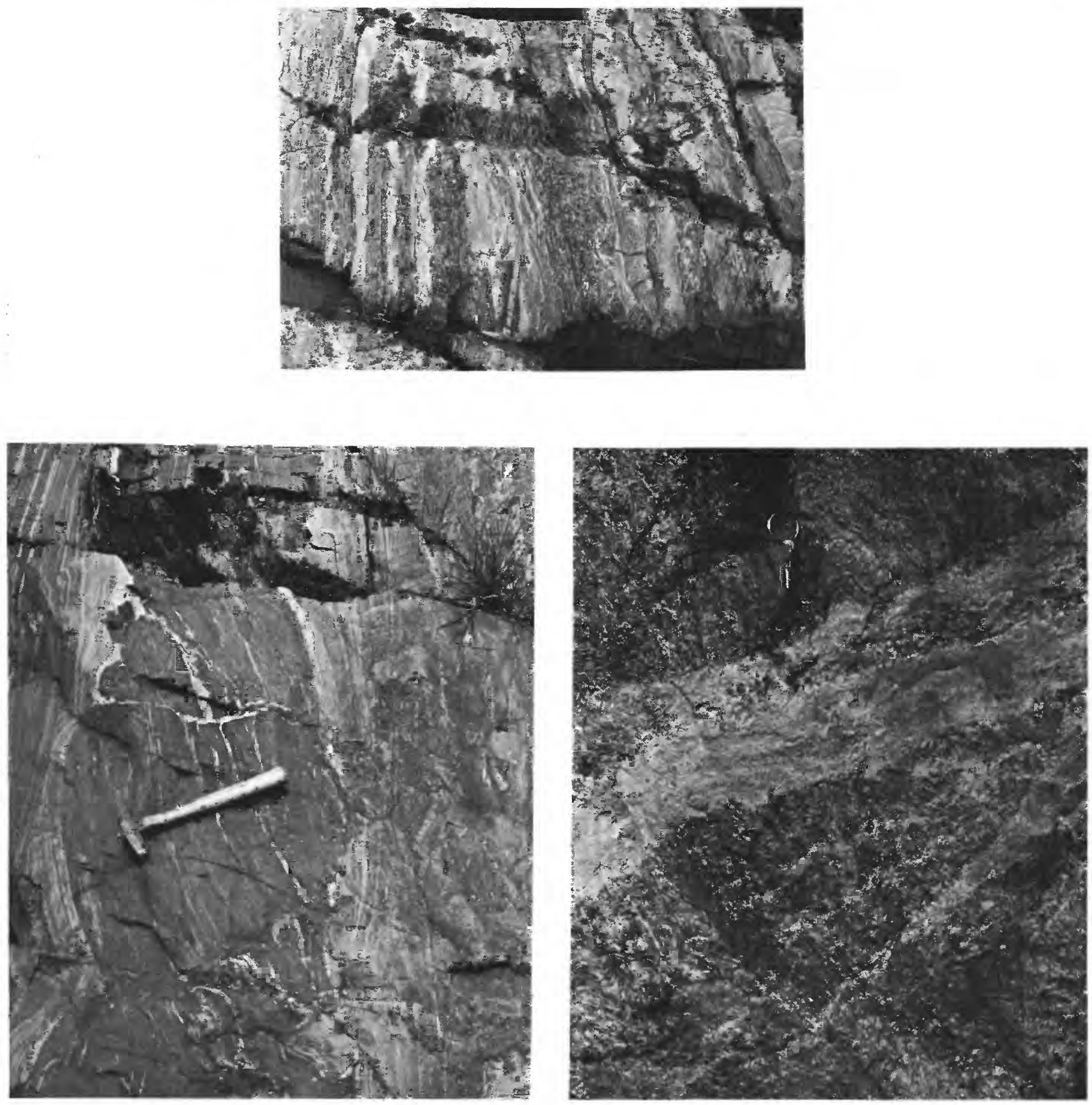

FIGURE 1.-TEXTURES AND STRUCTURES OF QUARTZITE, SCHIST, AND MIGMATITE.

A. Interlayed quartzite and migmatitic schist ("rhythmite"). South side of Bear Island, 0.5 mile upstream from mouth of Difficult Run.

$B$. Migmatitic schist with relict bedding foliation cut by dike of fine-grained granodiorite. Note faint flow structure and pegmatite core in dike. Northeast side of $\mathbf{C}$ and $\mathbf{O}$ Canal about 0.25 mile northwest of Widewater.

C. Boudinaged layer of fine-grained epidote-amphibole schist in thinly bedded quartzite. North side of Potomac River, 0.2 mile southeast of the eastern end of Sherwin Island. 


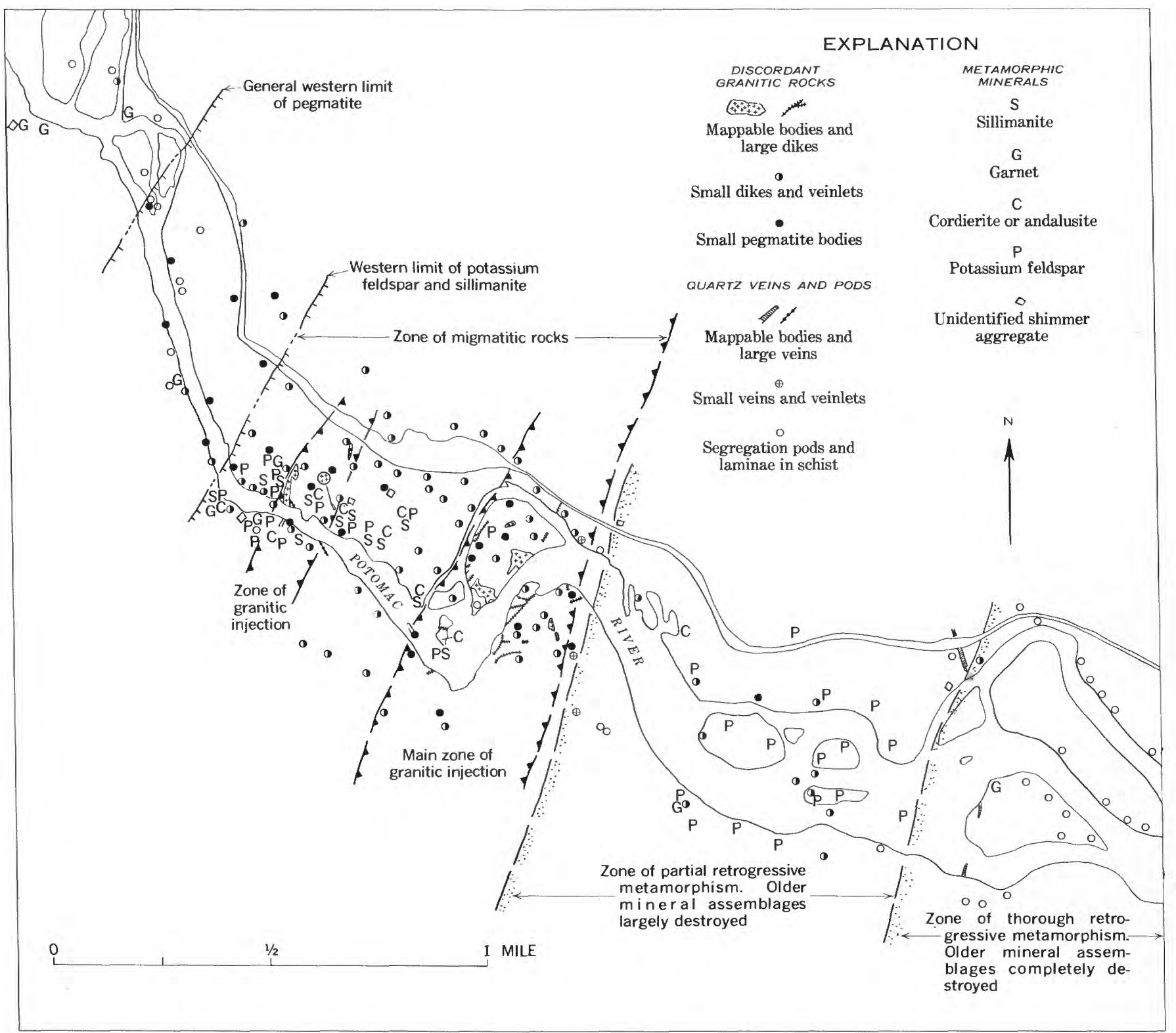

Frgure 2.-Distribution of discordant granitic bodies, pegmatite bodies, quartz veins, and selected metamorphic minerals.

gressive metamorphism, where it is intergrown with muscovite in folia parallel to both bedding-plane foliation and the younger cleavage; it also occurs in small randomly oriented flakes. In the more throughly retrogressively metamorphosed schists, biotite is partly or completely replaced by chlorite, which occurs as pseudomorphous flakes or as felted aggregates intergrown with sericite.

Sillimanite occurs in the schist in the Bear Island syncline (fig. 4). It generally forms less than 5 percent of the rocks in which it occurs, but locally forms as much as 20 percent. It occurs as sheaves or fans of fine needles within quartz, plagioclase, and mica, and as isolated individual needles as long as 1 inch. In the area of medium-grade rocks to the northwest, sillimanite is absent but the schist contains a few relict grains of kyanite, largely replaced by sericite aggregates.

Garnet (almandine?) occurs in small anhedral or euhedral grains in the medium- and high-grade schist (fig. 5). It is somewhat more common in the mediumgrade rocks than in the high-grade rocks. Much of the garnet is fractured and seamed by quartz, plagioclase, and chlorite. Where the rocks have been retrogressively metamorphosed, garnet is replaced by chlorite.

Relict grains of cordierite and andalusite, and aggregates of biotite and muscovite replacing them, are found locally in the schist adjacent to large amphibolite bodies in the Bear Island syncline (fig. 6). The cordierite and 


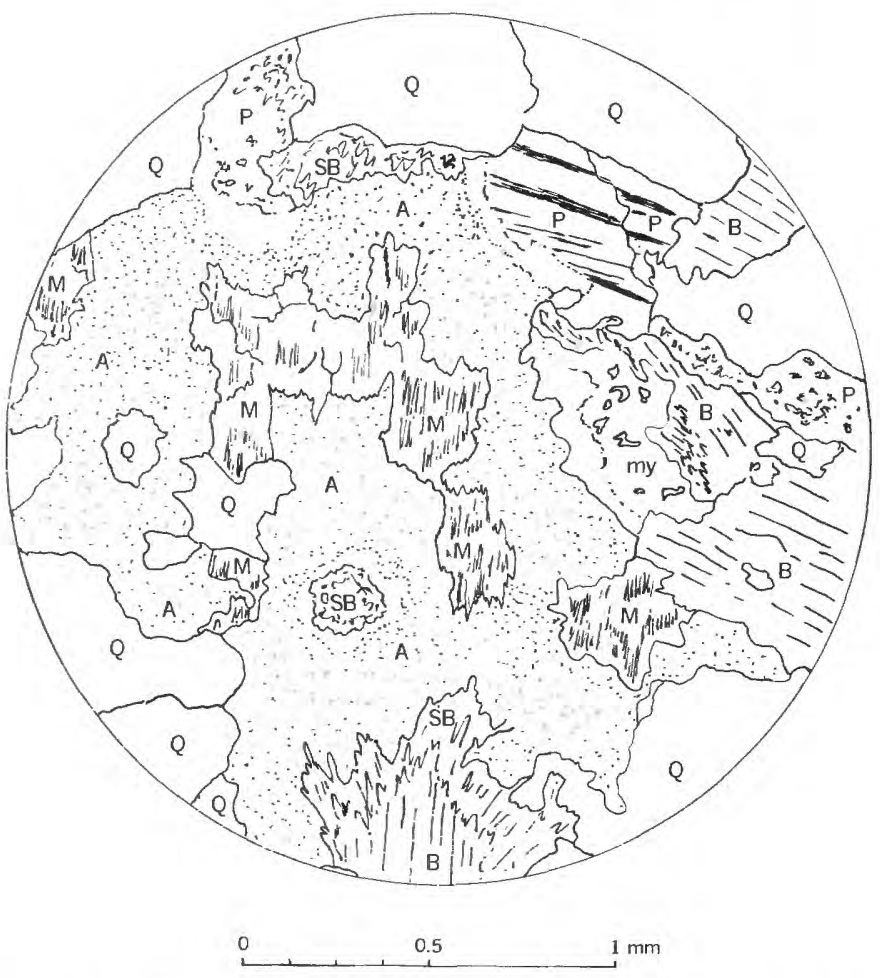

FIgURE 3.-Micrograph of albite replacement of microcline and older plagioclase in migmatitic sillimanite-bearing schist interlayered with quartzite near center of Bear Island, 0.6 mile northwest of mouth of Difficult Run. M, microline; my, myrmekite; B, biotite; $A$, albite $\mathbf{P}$, older plagioclase; $\mathbf{Q}$, quartz; $\mathbf{S B}$, sericite and bleached biotite.

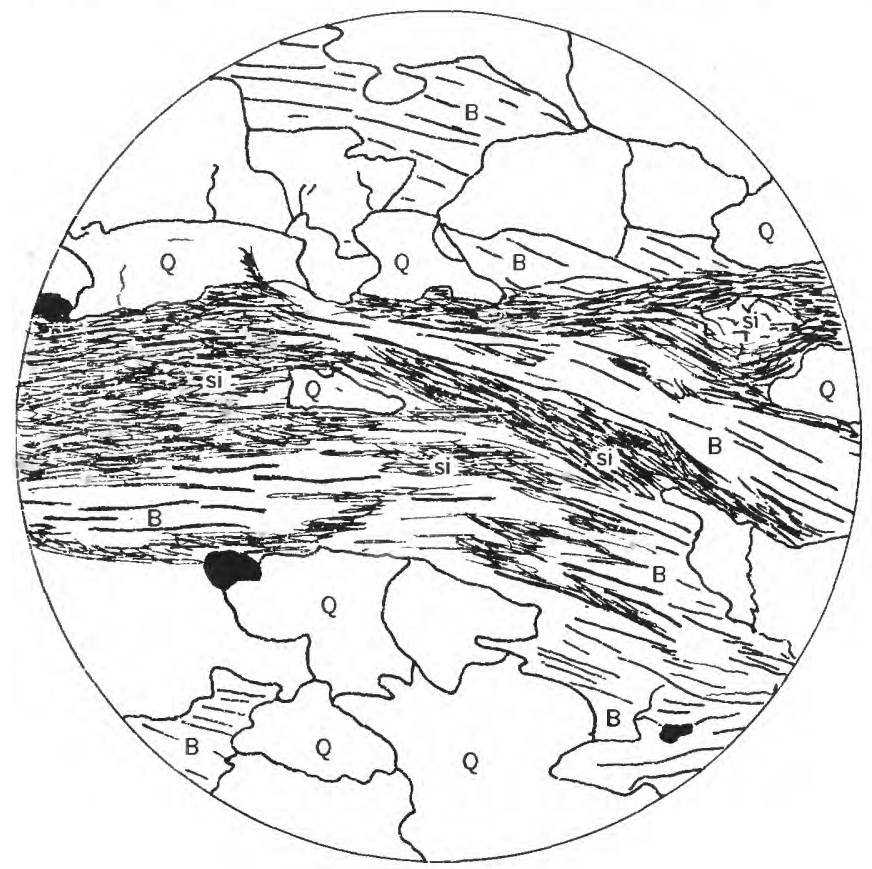

$\stackrel{0}{L}, \quad 0.5 \quad 1 \mathrm{~mm}$

FIGURE 4.-Micrograph of sillimanite replacement of blotite in schist from south end of small island 0.1 mile north of mouth of Difficult Run. Si, sillimanite; B, biotite; $Q$, quartz.

$681-3710-63-2$

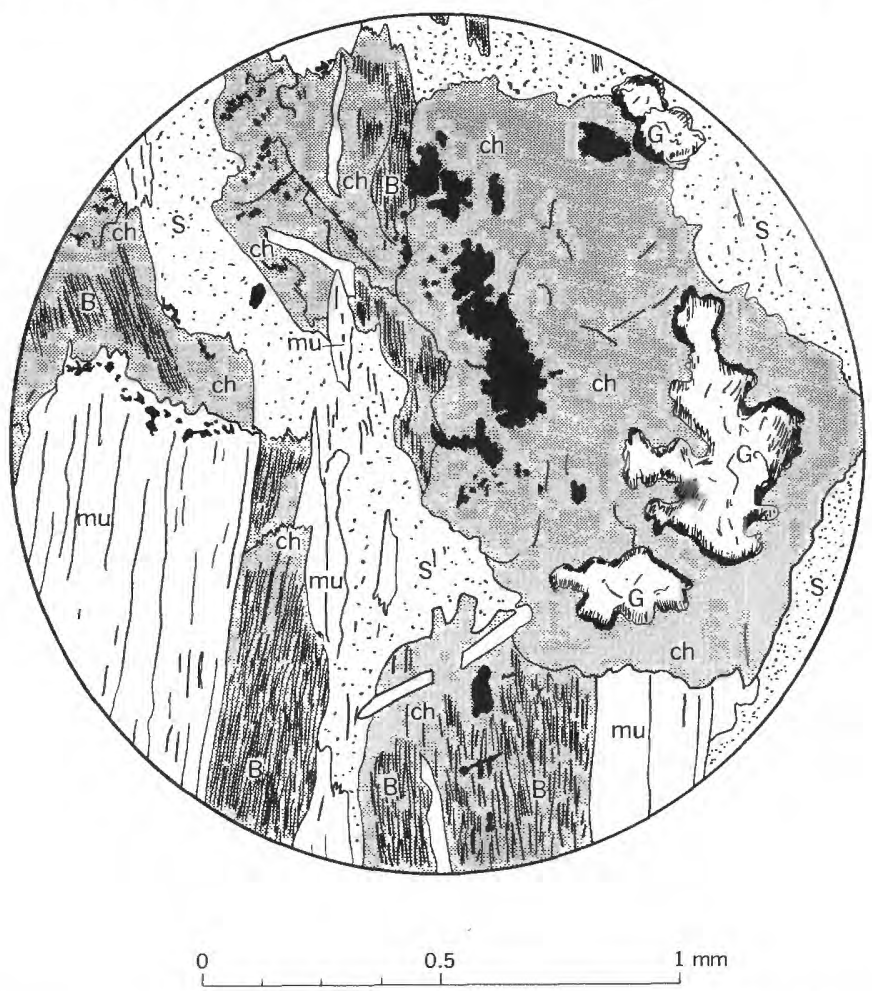

FIGURE 5.-Micrograph of garnet in schist from southwest side of the Potomac River, 0.6 mile above the mouth of Difficult Run. Garnet and biotite are partly replaced by chlorite. ch, chlorite; G, garnet; mu, muscovite; $B$, biotite; $\mathbf{S}$, sericite.

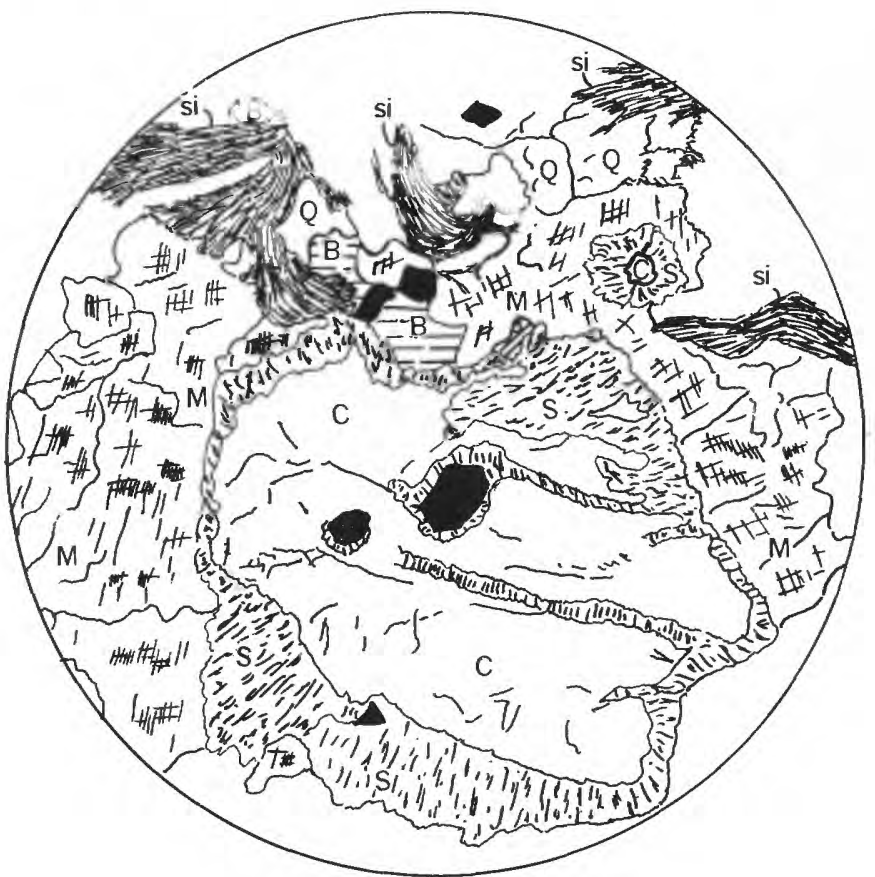

$0 \quad 2 \quad 4 \mathrm{~mm}$

FIGURE 6. Micrograph of cordierite in schist from south end of small island 0.1 mile north of mouth of Difficult Run. C, cordierite; $M$, microcline; $\mathbf{B}$, biotite; $Q$, quartz; $\mathbf{S}$, sericite ; si, sillimanite. 
andalusite appear to be highly deformed and locally are penetrated by undeformed sillimanite needles, suggesting that they formed before the peak of regional metamorphism, perhaps in contact-metamorphic aureoles around the amphibolite bodies. It is also possible, however, that the cordierite and andalusite formed during an early stage of the regional metamorphism.

Chief accessory minerals in the schist are allanite, sphene, tourmaline, apatite, and ilmenite. Epidote is absent in the medium- and high-grade rocks, but small quantities are present in the retrogressively metamorphosed schist.

The quartzite is a fine- to medium-grained, white or bluish-gray layered rock composed of quartz, plagioclase, biotite, muscovite, and chlorite, with minor amounts of garnet and other accessory minerals. Although the rock is referred to throughout this paper as quartzite, its original composition probably more nearly approached arkosic quartzite or subgraywacke. In some of the coarser quartzite near the bases of graded beds, rounded clastic grains of pink potassium feldspar and white and smoky quartz as much as 5 millimeters in diameter are preserved. In the finer grained quartzite, however, all traces of sedimentary texture have been erased by recrystallization.

The quartzite generally contains 60 to 90 percent quartz, 5 to 20 percent plagioclase, 5 to 10 percent muscovite or sericite, 0 to 10 percent biotite or chlorite, and smaller amounts of microcline, calcite, epidote, garnet, zircon, apatite, sphene, and opaque minerals. Quartz and cloudy oligoclase form a granoblastic mosaic; micaceous minerals occur in folia parallel to bedding or as scattered flakes parallel to cleavage; epidote and garnet commonly are concentrated in thin layers where their formation was favored by the original composition of the sediment.

Sillimanite and metamorphic microcline occur in the quartzite locally in the area of high-grade metamorphism, and detrital grains of microcline are found in the quartzite elsewhere. In the area of high-grade metamorphism, the quartzite commonly displays $1 / 4$ - to $1 / 2$-inch elliptical spots (fig. 7 ) composed of aggregates of biotite and sericite, surrounded by bleached halos in the enclosing rock. These spots may be derived from cordierite porphyroblasts similar to those in the schists in the same area.

Fine-grained light-green calc-silicate rocks occur locally as thin layers and pods intercalated with schist and quartzite. The calc-silicate layers rarely exceed 1 inch in thickness, and are generally broken into pods or boudins 6 inches to 1 foot long. They consist of quartz and epidote, and small amounts of plagioclase, actino- lite, garnet and locally diopside. They were probably derived from thin calcareous layers or concretions.

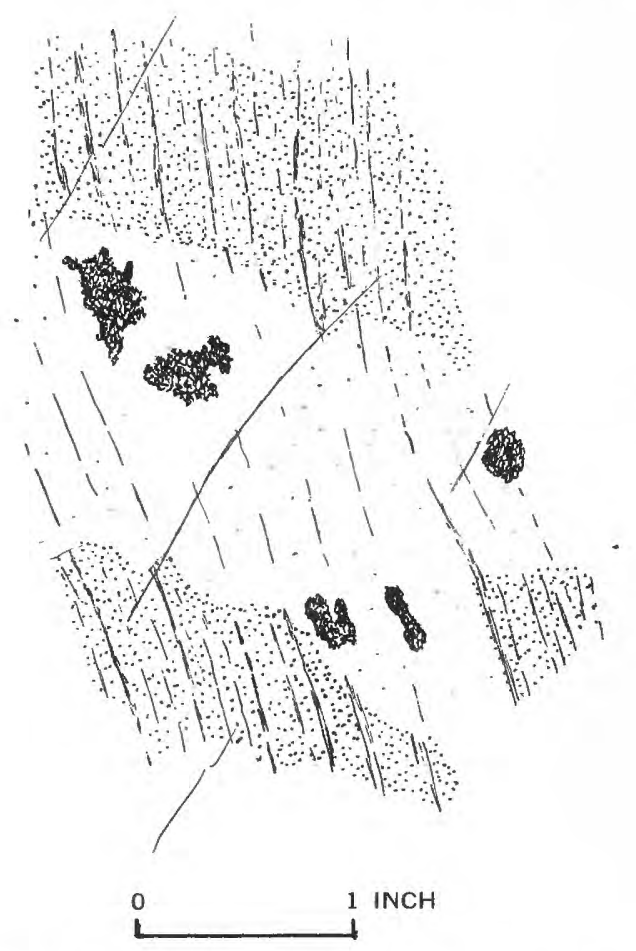

\footnotetext{
FigURE 7.-Sketch of spotted quartzite adjacent to the amphibolite body near south end of Bear Island. Dark spots are biotite-sericite aggregates probably replacing cordierite. Normal quartzite (stippled) is medium or dark gray owing to finely disseminated biotite. Adjacent to the dark spots biotite is absent and the quartzite is white.
}

Dark-green fine-grained amphibole schist occurs in a few places as layers 2 inches to 3 feet thick, interlayered with micaceous schist and quartzite. The amphibole schist contains chlorite, epidote, and actinolite in areas of retrogressive metamorphism, and biotite and hornblende in other areas. Some layers can be traced for more than 100 feet along strike, parallel to the bedding of the enclosing rocks, and vary little in thickness except for boudinage effects (fig. $1 C$ ). The mineralogy of these layers, the internal layering they show in places, their lateral extent, and their intimate interlayering with schist and quartzite indicate that they were derived from sedimentary rather than igneous rocks.

\section{AMPPHBOIITE}

Dark coarse- to fine-grained amphibolite is intercalated with schist and quartzite in the Bear Island syncline and in the Anglers Inn syncline. Similar amphibolite bodies on the south shore of the river south of Vaso Island may also be in a synclinal trough. These amphibolite bodies are as much as 300 feet wide in outcrop on the noses of folds on Bear Island, but they 
do not exceed 100 feet in width on the fold limbs. They are generally conformable with the bedding of the enclosing rocks, although mobilized migmatitic schist intrudes between boudins of amphibolite in many places. The amphibolite bodies thus appear to be folded and boudinaged remnants of one or more sill-like bodies.

The amphibolite in the central parts of the bodies is a very coarse grained dark-green nonfoliated rock consisting of close-packed irregular subspherical clots of hormblende as much as half an inch in diameter in a fine-grained matrix. The rock typically contains 60 to 65 percent hormblende, 10 to 15 percent plagioclase, 10 to 20 percent quartz, 1 to 5 percent biotite, 5 to 10 percent opaque minerals, and minor amounts of epidote, apatite, chlorite, and calcite. The hornblende is pleochroic from grass green to yellowish green to brownish green and occurs in single sieve-textured grains or aggregates of grains in subparallel orientation. The matrix consists of a granoblastic mosaic of plagioclase, quartz, and small grains of green hornblende, opaque ores, epidote, and clinozoisite. Irregular flakes of darkbrown biotite are associated with the larger amphibole grains in some specimens, and chlorite and calcite are common minor accessories. Small crystals and remnants of pigeonite in parallel orientation to and partly replaced by amphibole occur in a few specimens.

The plagioclase is clear andesine, somewhat twinned, and in some specimens zoned. Some andesine grains have oligoclase rims.

Near the margins of the amphibolite bodies, the grain size decreases, and foliation and lineation are developed. This marginal phase of the amphibolite is a fine-grained dark-green schistose rock consisting of hornblende in a mosaic of epidote, oligoclase, and chlorite and diffuse areas of granoblastic quartz. The hornblende is strongly pleochroic from blue green to green to yellow. It displays low first-order birefringence and is apparently more sodic than the hornblende in the central parts of the amphibolite bodies.

Breccia composed of angular amphibolite blocks in a matrix of granodiorite is common along the borders of some of the larger amphibolite bodies (fig. 8). The margins of the amphibolite blocks contain abundant biotite, which is present only in minor amounts within the blocks.

The coarse texture of the amphibolite and the occurrence of relict pigeonite in it indicate that the rock was derived from mafic igneous rock, probably diabase or gabbro. Andalusite and cordierite in the adjacent schist and quartzite may have been produced by contact metamorphism at the time of intrusion.

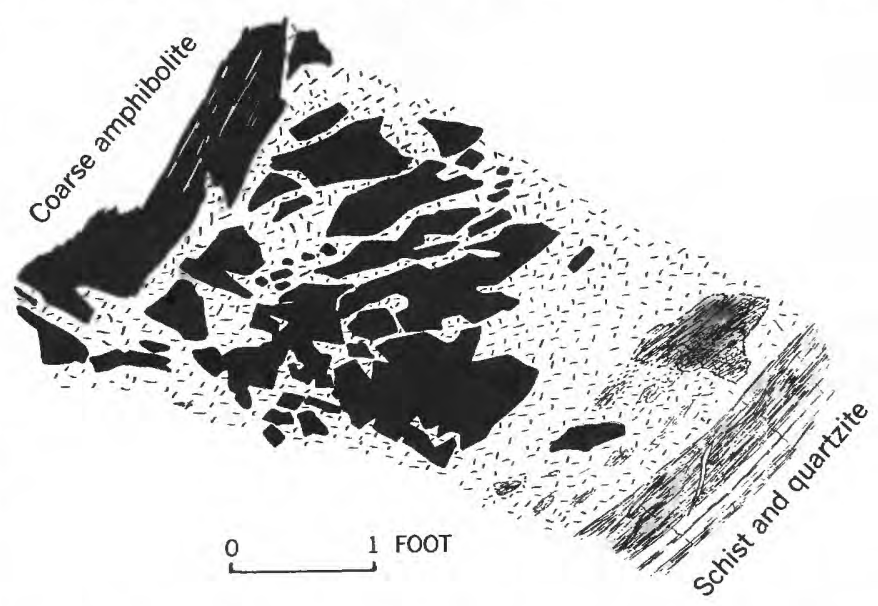

Figure 8 - Sketch of breccia of angular amphibolite blocks in matrix of white inequigranular granodiorite, at contact of the large amphibolite body near the south end of Bear Island.

\section{CHLORITE-MUSCOVITE GNEISS}

The schistose chlorite-muscovite gneiss that crops out east of the Anglers Inn syncline was mapped as Sykesville Formation by Cloos and Cooke (1953); however, it does not resemble the rock described by Stose and Stose (1946) in the type area of the Sykesville Granite. ${ }^{1}$ Moreover, the area in this part of the Potomac Gorge mapped as Sykesville Formation by Cloos and Cooke (1953) is not continuous with the main body of rock mapped as Sykesville Formation from central Montgomery County northward to the type area. (See pl.1.)

In the area mapped the gneiss is a medium- to finegrained strongly foliated and locally banded light- to dark-gray or greenish-gray rock that has a granitic appearance in hand specimen. The rock commonly contains abundant feldspar augen ranging from $1 / 4$ to 2 inches in diameter, which stand out as bone-white or yellowish bumps on weathered surfaces. The rock becomes more schistose toward the margins of the body and gradually loses its granitic aspect, passing gradationally into the surrounding schist. Schistosity in the gneiss is parallel to the regional schistosity in the surrounding rocks.

In many places the gneiss contains pods of mica schist, quartz, quartzite, and chlorite-epidote-actinolite schist ranging in length from less than 1 inch to as much as 2 feet (fig. 9A). Most of these pods are flattened parallel to the schistosity and elongated parallel to north- or northwest-plunging mineral lineation.

1 The term Sykesville Granite was used on the geologic map of Carroll County, Md. (Jonas, 1928) but was modified to Sykesville Formation by Cloos and Broedel (1940). Stose and Stose (1946) retain the term Sykesville Granite. Neither term has been adopted for use by the U.S. Geological Survey. 
Chlorite-epidote-actinolite schist occurs in isolated blocks and remnants of boudinaged layers, commonly with fine-grained leucocratic granodiorite or quartz diorite between and partially surrounding the blocks. Amphibole has been largely converted to biotite or chlorite.

Small dikes of similar granitic rock, apparently identical with granitic rocks that are abundant farther to the west, cut the gneiss, and some are broken and offset along the schistosity of the gneiss (fig. $9 B$ ).

The gneiss consists predominantly of muscovite and sericite, chlorite, quartz, and plagioclase (mostly albite), and variable but minor amounts of biotite, epidote, and opaque minerals. Potassium feldspar is

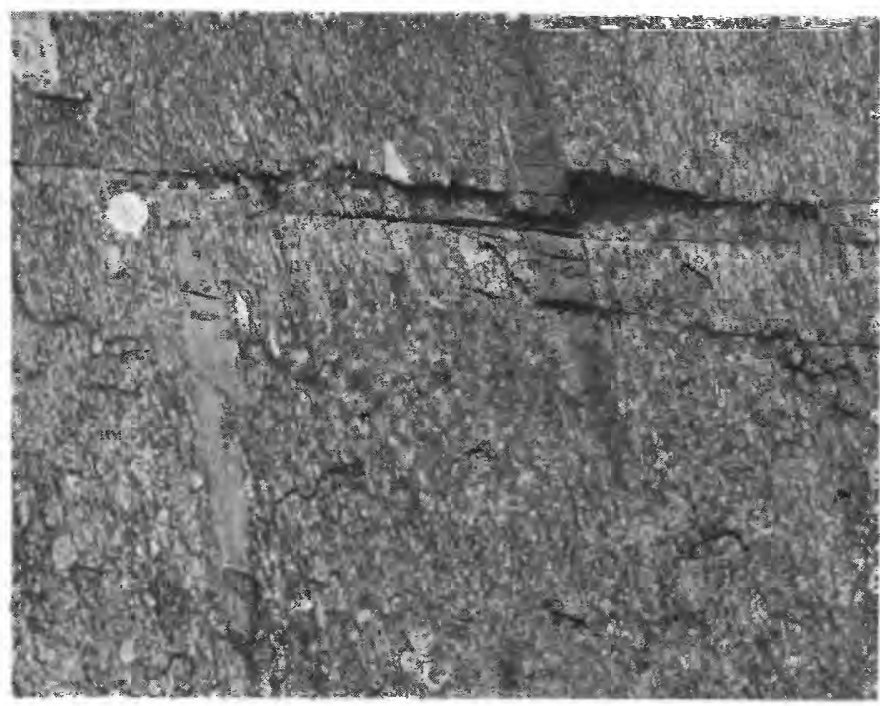

A. Gneiss with tabular inclusions of fine-grained dark epidoteamphibole schist and light-colored quartzite. South side of Potomac River opposite Perry Island.

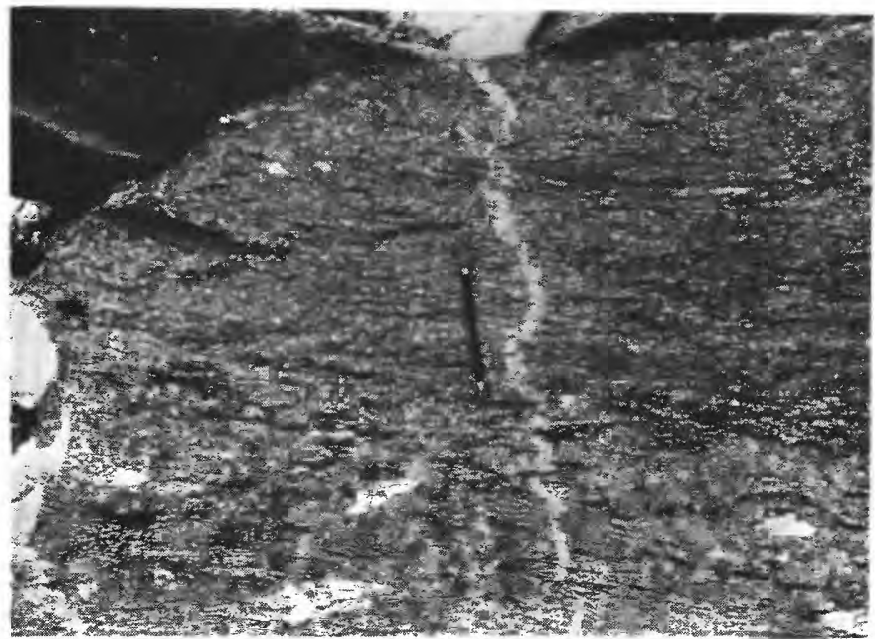

$B$. Thin dike of fine-grained, light-colored granodiorite cutting gneiss Note offset of dike along cleavage planes. South side of Perry Island.

FIGURE 9.-TEXTURES AND STRUCTURES OF CHLORITE-MUSCOVITE GNEISS. present only in minor amounts. Feldspar porphyroclasts a few millimeters to several centimeters in diameter (fig. 10) are set in an inequigranular mosaic of

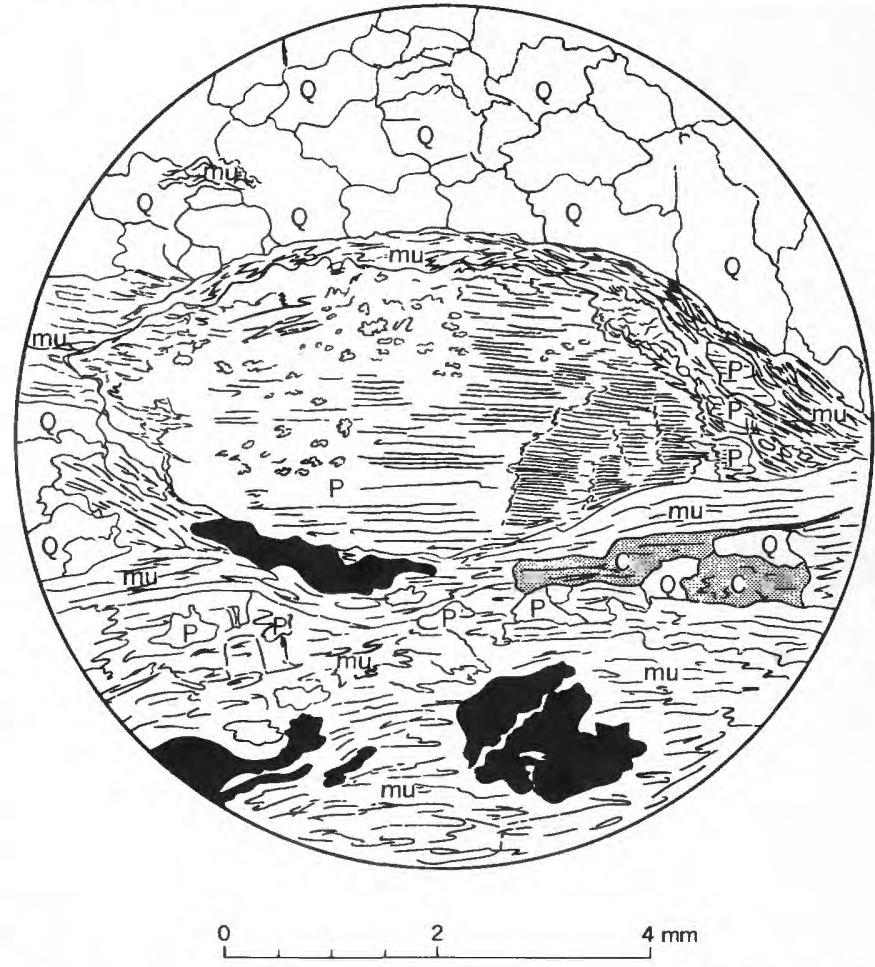

FigdRE 10.-Micrograph of plagioclase porphyroclast in gneiss from north of the Potomac River opposite Hermit Island. P, plagloclase ; mu, muscovite; $C$, chlorite; $Q$, quartz.

quartz, albite, sericite, muscovite, and chlorite. Schistosity is defined by subparallel micaceous folia, quartz segregation laminae, and zones of fractured grains and mortar structure. Muscovite and chlorite occur in welloriented flakes, many of them bent, and in masses wrapped around porphyroclasts. Biotite appears older and more deformed than most of the chlorite and muscovite; it is largely replaced by chlorite.

Allanite occurs in micas in small reddish grains surrounded by radiogenic halos, and as cores of epidote grains. Calcite is commonly associated with epidote and chlorite. Euhedral pyrite crystals and chlorite pseudomorphs after garnet (?) occur in a few specimens.

Many of the feldspar porphyroclasts are oligoclase, clouded with minute inclusions of epidote and sericite, and rimmed and partially replaced by albite. Patchy inclusions of quartz and incipient twinning are common in the large crystals. The grains are fractured and twin lamellae are bent or disoriented. Some of the porphyroclasts are patchy spindle-twinned microcline, which has been shattered and partly albitized and sericitized. Locally, myrmekite is developed adjacent to the albite 
rims, and in some specimens quartz-muscovite symplektite has apparently replaced microcline.

Albite occurs as rims and irregular patches in and around other feldspars and as large poikiloblastic porphyroblasts with irregular inclusions of quartz, muscovite, and chlorite, and broken pieces of other feldspars.

Near the margins of the gneiss, sericitization is extensive and feldspar porphyroclasts and albite porphyroblasts are largely replaced by masses of sericite and quartz surrounding clusters of clinozoisite and epidote.

The origin of the chlorite-muscovite gneiss is not clear. Similarity between the mineral composition of the gneiss and that of the surrounding schist, gradational contacts of the gneiss, and "inclusions" in the gneiss of rocks that are common as layers in the surrounding rocks suggests that the gneiss was produced from the enclosing rocks. The gneiss is a product of granitization in the sense that its appearance is more "granitic" than the schist from which it was derived (Grout, 1941), but the change was almost entirely textural, without appreciable change in composition. The pods of quartzite and amphibole schist are probably deformed fragments of layers in the schist that were torn apart during deformation. Apparently undeformed dikes of quartz diorite or granodiorite cut some of the deformed fragments, showing that most of the deformation occurred before intrusion of the dikes; but a few similar dikes are broken and offset along the cleavage planes (fig. $9 B$ ), indicating that some movement occurred after emplacement of the dikes.

The presence of porphyroclasts of albitized oligoclase and microcline suggests that the rock may have formed at a metamorphic grade high enough for these minerals to grow as porphyroblasts. Chloritization, sericitization, and the growth of albite porphyroblasts occurred at a lower grade, under more hydrous conditions, probably during or after the deformation that dislocated the quartzite and amphibole schist layers. The zones of microscopic fracturing and mortar structure probably represent late-stage granulation after emplacement of the granitic dikes.

Chapman (1942) studied the Laurel Gneiss, a rock very similar to the chlorite-muscovite gneiss in the $\mathrm{Po}$ tomac Gorge, and concluded that it formed by granulation, flowage, and recrystallization of the Wissahickon Formation, without appreciable introduction of material. We suggest that the gneiss in the Potomac Gorge formed through similar processes. The structural and stratigraphic significance of the gneiss, however, and its relation to other rocks mapped as Sykesville Formation by Cloos and Cooke (1953) are not yet well known.

\section{GRANITIC ROCKS}

Light-colored fine- to medium-grained granitic rocks, ranging in composition from quartz diorite to quartz monzonite, form dikes, sills, and small irregular plugs which cut all the other bedrock units exposed in the area. These rocks were called the Bear Island Granodiorite by Cloos and Cooke (1953).

The granitic rocks consist of quartz, albite or oligoclase, and muscovite, varied amounts of potassium feldspar, and small amounts of biotite and other minerals. Grains of cloudy plagioclase 0.5 to 1 millimeter in diameter are scattered in a finer granoblastic mosaic of unstrained quartz and cloudy plagioclase. Muscovite occurs in clear fresh books without conspicuous orientation and in quartz-muscovite symplektites.

Microcline occurs as large grid-twinned, untwinned, or patchy-twinned crystals. Both replacement and exsolution perthitic structures and chessboard albite are common. Where the rocks have been albitized, microcline is almost entirely replaced by albite or muscovite.

Most of the albite seems to have formed late, for it commonly occurs as large undeformed poikiloblastic crystals and as clear rims around altered or deformed plagioclase. The older plagioclase is sericitized oligoclase that is commonly strongly zoned and displays Carlsbad, pericline, and albite twinning.

Garnet occurs in some rocks as inclusions in plagioclase or muscovite. Epidote-biotite, biotite-muscovite-epidote, and muscovite-epidote intergrowths are widespread; the muscovite-epidote intergrowths are generally adjacent to masses of sphene and leucoxene. Some of these aggregates appear to be pseudomorphs after pyroxene or amphibole. Sphene occurs along biotite cleavages and in small aggregates.

The granitic bodies are numerous in and adjacent to the zone of highest regional metamorphism, but a few crosscutting dikes occur as far upstream as Great Falls and as far downstream as Perry Island, where they cut the chlorite-muscovite gneiss (fig. 2). The largest granitic bodies are as much as 200 feet wide and have irregular angular outcrop patterns which sharply truncate structures of the enclosing rocks. Some of the granitic rocks display flow banding parallel to their walls. Cleavage is lacking in the granitic rocks except in a very few places, and locally the granitic rocks contain rotated inclusions of wallrocks (fig. 11). The dikes range from a few inches to as much as 20 feet in thickness and transect the wallrocks at all angles; many occupy pressure shadows between boudins and adjacent to competent blocks of quartzite or amphibolite. In several places adjacent to the amphibolite bodies, the granitic rock forms the matrix of a breccia of angular amphibolite blocks 6 inches to 15 feet in diameter. 


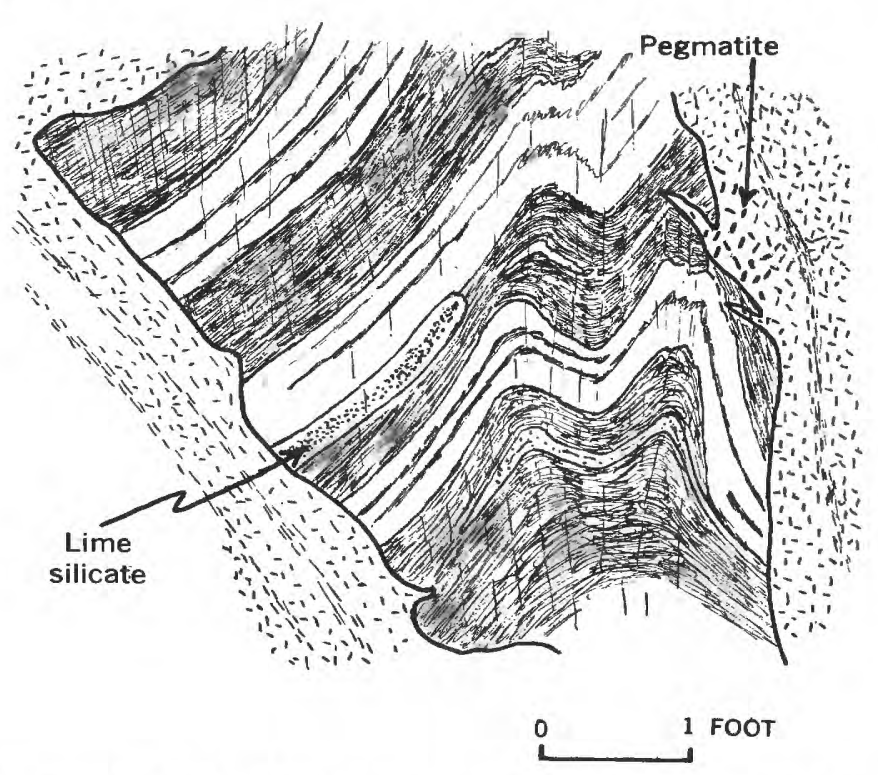

Figure 11.- Sketch of inclusion of quarzite and schist in granitic body exposed in the bed of the $C$ and $O$ Canal, 0.1 mile east of Widewater. Fold axes in the inclusion are nearly vertical; those in the wallrocks plunge gently north, indicating that the block has been rotated nearly $90^{\circ}$. Note rude flow structure in the granitic rock.

Many of the granitic bodies have sharp contacts, but in some places contacts are diffuse and gradational, and thin septa of schist project into and nearly across dikelike bodies of granite (fig. 12). Where granitic bodies occur in migmatitic rocks the quartzofeldspathic folia in the wallrocks are indistinguishable from the granitic rock.

The granitic bodies that show flow structures, rotated inclusions, and sharp contacts are clearly intrusive; but for the bodies with gradational contacts and thin unrotated schist septa, the field evidence indicates a replacement origin. The transition of some of the granitic bodies into migmatites suggests that the granitic material is largely or entirely of local derivation and that the crosscutting intrusive bodies are composed of material that has been locally segregated and mobilized. The concentration of the granitic bodies in and near the zone of migmatization and sillimanite-grade regional metamorphism indicates that the granitic material was formed during this episode; but the sharp angular contacts of the discordant bodies and lack of cleavage in the granitic rocks suggest that mobilization and intrusion followed somewhat after the metamorphic climax.

\section{PEGMATITES AND VEINS}

Dikes and irregular bodies of coarse-grained pegmatite as much as 2 feet in diameter are associated with discordant granitic bodies and are most common near the margins of the areas of migmatitic rocks (fig. 2). The pegmatites consist of quartz, plagioclase, and po- tassium-feldspar anhedra $1 / 2$ to 2 inches in diameter, and commonly contain muscovite books as much as 1 inch in diameter. Some pegmatites pass laterally into quartz veins and others grade into the finer grained granitic rocks.
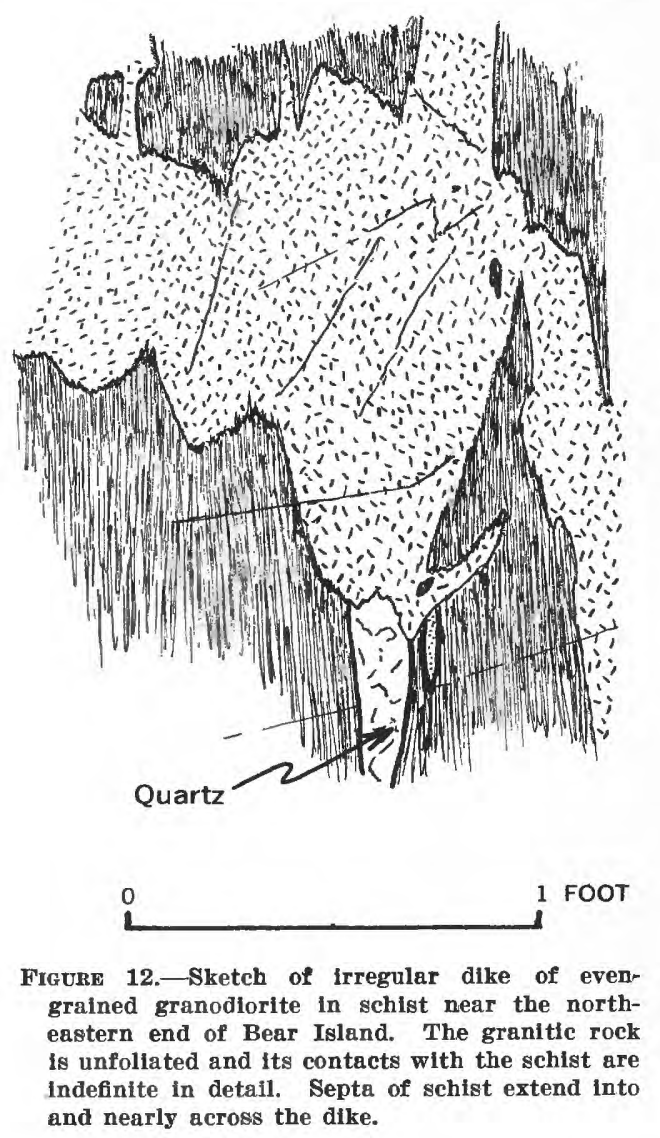

Pods and veins of quartz occur throughout the area (fig. 2). The quartz veins range from thin coatings on joint surfaces to sheets 20 feet thick. Some of the granitic dikes and pegmatites pass into veins consisting mostly of quartz, but the largest veins are not obviously related to the granitic rocks. Quartz pods and knots in the schist are most abundant where retrogressive metamorphism has been most thorough. The quartz veins contain pyrite, apatite, tourmaline, allanite, epidote, specular hematite, calcite, and chlorite. Gold has been mined from quartz veins in several nearby areas (Ulke, 1939; Ingalls, 1961), but the gold-bearing veins were not examined during the present study.

\section{STRUCTURE}

The overall structural complexity of the rocks exposed in the Potomac Gorge is evident from the geologic map (pl. 2). This pattern results from the superposition of structures of at least two generations on a stratigraphically complex sequence of bedded rocks. The 
first generation of structures formed prior to the emplacement of the discordant granitic rocks, probably during the episode of medium- and high-grade regional metamorphism. The second generation was apparently associated with low-grade retrogressive metamorphism after emplacement of the granitic bodies.

\section{BEDDING AND BEDDING FOLIATION $\left(\mathrm{S}_{1}\right)$}

Unmodified sedimentary structures can be identified only in the cleaner quartzite layers, where heavy mineral streaks, crossbedding, and graded bedding have locally survived deformation and metamorphism. In the more schistose rocks a mechanical foliation parallel to layering is marked by alinement of micaceous folia and thin quartz or quartz-feldspar laminae. Close examination shows that the layers are discontinuous lenses, not continuous beds, and that the structure is a bedding foliation formed by slippage and recrystallization along bedding planes during deformation, rather than true bedding.

Even where quartzite and schist are regularly interlayered, variation in thickness of layers in small folds shows that the contacts between layers with different mechanical properties, as well as the foliation planes within the layers, must have acted as surfaces of slip during deformation, and that the thickness of the individual layers is therefore of little stratigraphic significance. Bedding and bedding foliation are collectively referred to as $S_{1}$ throughout this paper, although it is clear that one is a relict primary structure and the other is a structure formed during deformation and recrystallization.

\section{STRUCTURES OF THE FIRST GENERATION}

\section{B-FOLDS}

$S_{1}$ is folded around gently or moderately plunging north-south trending axes. The folds, referred to as $B$-folds, have steeply dipping axial planes and tightly to moderately appressed limbs.

Observed $B$-folds range in amplitude from a fraction of an inch to several tens of feet; larger folds of this generation are inferred from mapping (pl. 2). Individual layers are thickened in the fold noses and thinned or elided on the limbs; the thickness of layers is variable, both normal to the layering and parallel to the axial planes (fig. 13). This shows that formation of the folds could not have been entirely by flexure or entirely by slip parallel to the axial planes, but must have involved flowage into the noses along $S_{1}$ planes.

$B$-folds are best displayed in the central and northwestern parts of the area. In the eastern part of the area they are rarely seen, owing to scarcity of quartzite layers in the schist.

\section{CLFAvAGE $\left(\mathbf{S}_{2}\right)$}

Cleavage parallel to the axial planes of $B$-folds transects $S_{1}$ structures in the fold noses. This cleavage, designated $S_{2}$ is commonly marked by closely spaced slip planes which offset the $S_{1}$ planes as much as several millimeters (fig. 13). $S_{2}$ cleavage is parallel or subparallel to axial planes of $B$-folds and to $S_{1}$ in fold limbs. In schistose rocks $S_{1}$ is locally discernible as rootless isoclinal hinges between $S_{2}$ planes, but in many places $S_{1}$ and $S_{2}$ are indistinguishable.

In the medium-and high-grade rocks $S_{2}$ is primarily a mechanical structure accompanied by little or no mineral alinement, although locally biotite and muscovite flakes are oriented parallel to the $S_{2}$ planes. In the retrogressively metamorphosed rocks, alinement of sericite, chlorite, and quartz laminae parallel to the planes is conspicuous.

\section{LINEATION (Li)}

Fold and crenulation axes and $S$-plane intersections are designated as $L_{1}$ lineations. Most of these structures were formed during the first deformation, but a few similar structures dating from the second deformation are included. The crenulations are small wrinkles in micaceous partings along $S_{1}$ surfaces, some apparently small-scale $B$-folds and some produced by wrinkling of the $S_{1}$ surfaces by $S_{2}$ cleavage. Most of the $S_{1}-S_{2}$ intersections measured are marked by quartzitic bands or by elongate pods or micaceous streaks on $S_{2}$ surfaces, which represent cross sections of quartzitic layers or lenses, or micaceous folia parallel to $S_{1}$.

\section{STRUCTURES OF THE SECOND GENERATION}

CleAvage $\left(\mathbf{S}_{8}\right)$

Cleavage that locally transects $S_{2}$ planes is designated $S_{3}$. The $S_{3}$ cleavage is a widely spaced slip cleavage which wrinkles or offsets $S_{2}$ planes. Where the $S_{3}$ cleavage is best developed, the planes are spaced 0.5 to 1 centimeter apart and offset the older $S$ planes by a few millimeters. $S_{3}$ cleavage is locally developed in the central and eastern parts of the area but is not recognizable in the northwestern part. The $S_{3}$ planes are primarily slip planes, but locally sericite and chlorite flakes are oriented along them. The $S_{3}$ cleavage is only identifiable where it is at an angle to $S_{2}$; in the retrogressively metamorphosed rocks in the eastern part of the area the conspicuous regional cleavage is thought to be $S_{2}$ that has been reactivated during the second deformation, but it may in part be $S_{3}$ that has obliterated $S_{2}$.

Intersections of $S_{3}$ with $S_{1}$ and $S_{2}$ are marked by crenulations in the older structures transverse to $L_{1}$ lineations formed during the first deformation, but distinguishable from the older $L_{1}$ only where both struc- 


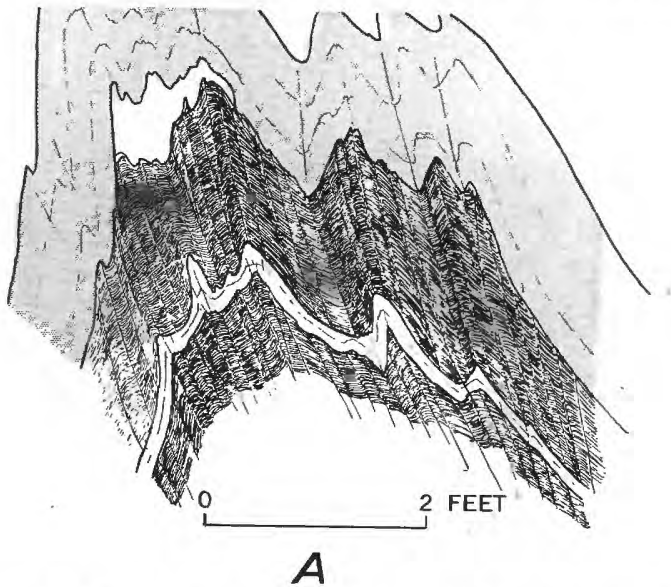

$A$. Nose of $B$-fold in interlayered mica schist and quartzite on west side of $\mathbf{C}$ and $\mathrm{O}$ Canal, 0.55 mile northwest of Widewater. Bedding foliation in schist is cut by slip cleavage $\left(S_{2}\right)$ parallel to axial planes of minor folds.

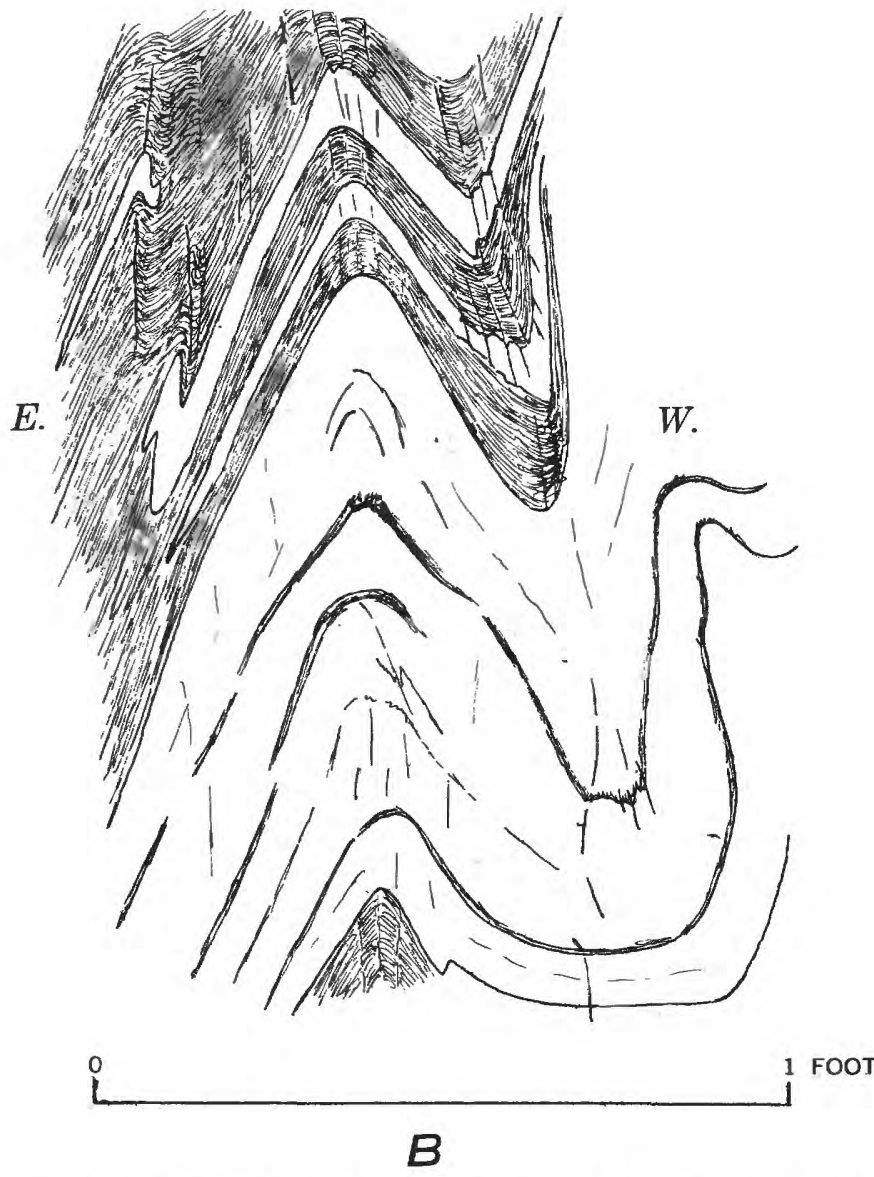

$B$. $B$-fold in quartzite and schist on north side of the Potomac River near the axis of the Anglers Inn syncline. Axial plane of this fold is parallel to the $S_{2}$ cleavage. In this outerop open $B^{\prime}$-folds (not shown in sketch) are superimposed on limbs of the fold sketched.

FIGURE 13. - SKETCHES OF TYPICAL B-FOLDS.

tures are recognizable in the outcrop. In a few places small folds in $S_{1}$ (designated $B^{\prime}$-folds) with axial planes parallel to $S_{3}$ are found (fig. 14), but such folds are rare.

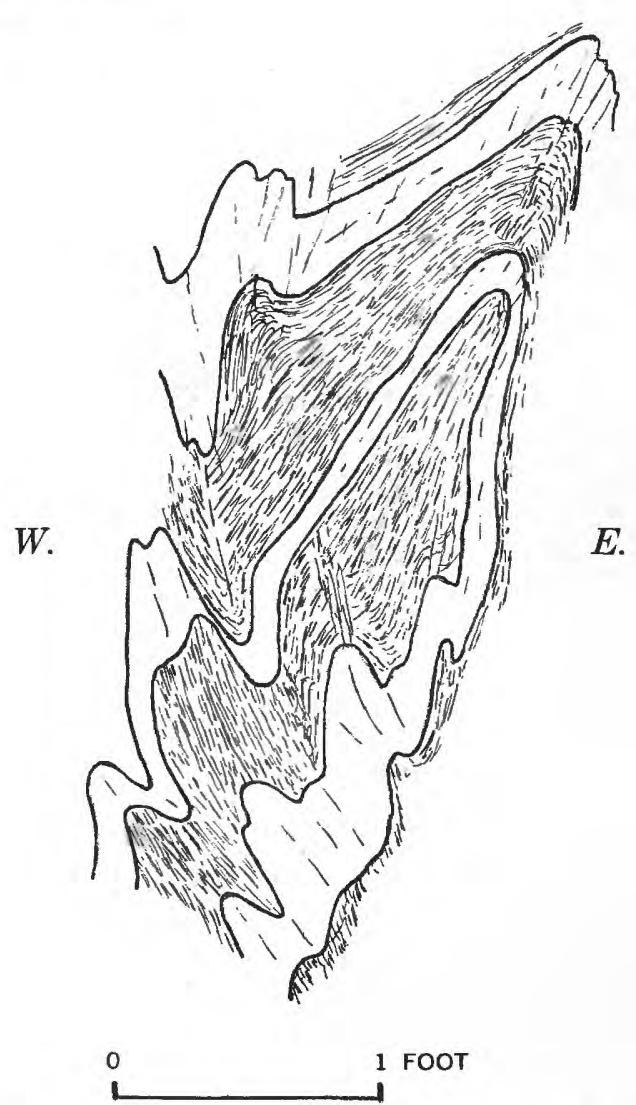

\begin{abstract}
Figure 14.- Sketch of ${ }^{\prime}$ '-folds superimposed on $B$-folds in migmatitic schist and quartzite. South west side of the Potomac River, 0.4 mile upstream from the mouth of Difficult Run. Younger folds with axial planes dipping east are superimposed on older isoclinal folds with axial planes dipping west. Exposures showing two generations of folds are rare.
\end{abstract}

\section{LINEATION $\left(\mathbf{L}_{2}\right)$}

Lineations marked by alinement of mineral grains and aggregates on $S$ planes are designated $L_{2}$. These lineations consist of elongate quartz pods and lentils, sericite and chlorite aggregates on $S$ planes in schist, and alined amphibole prisms in the schistose marginal facies of the amphibolite. $L_{2}$ occurs on steeply dipping $S$ planes of all types, but is generally absent on $S_{1}$ planes in fold noses. It is found throughout the area but is most conspicuous in the low-grade retrogressively metamorphosed rocks in the eastern part of the area, where it lies on $S_{2}$ planes. Most $L_{2}$-lineations are transverse to $L_{1}$ and are younger than $L_{1}$ formed during the first deformation, but some lie parallel to intersections of $S_{2}$ with $S_{1}$ and may have formed during the first deformation.

\section{GEOMETRY OF THE STRUCTURES}

The orientations of the various structures are summarized in the diagrams in figure 15. Separate sets of 


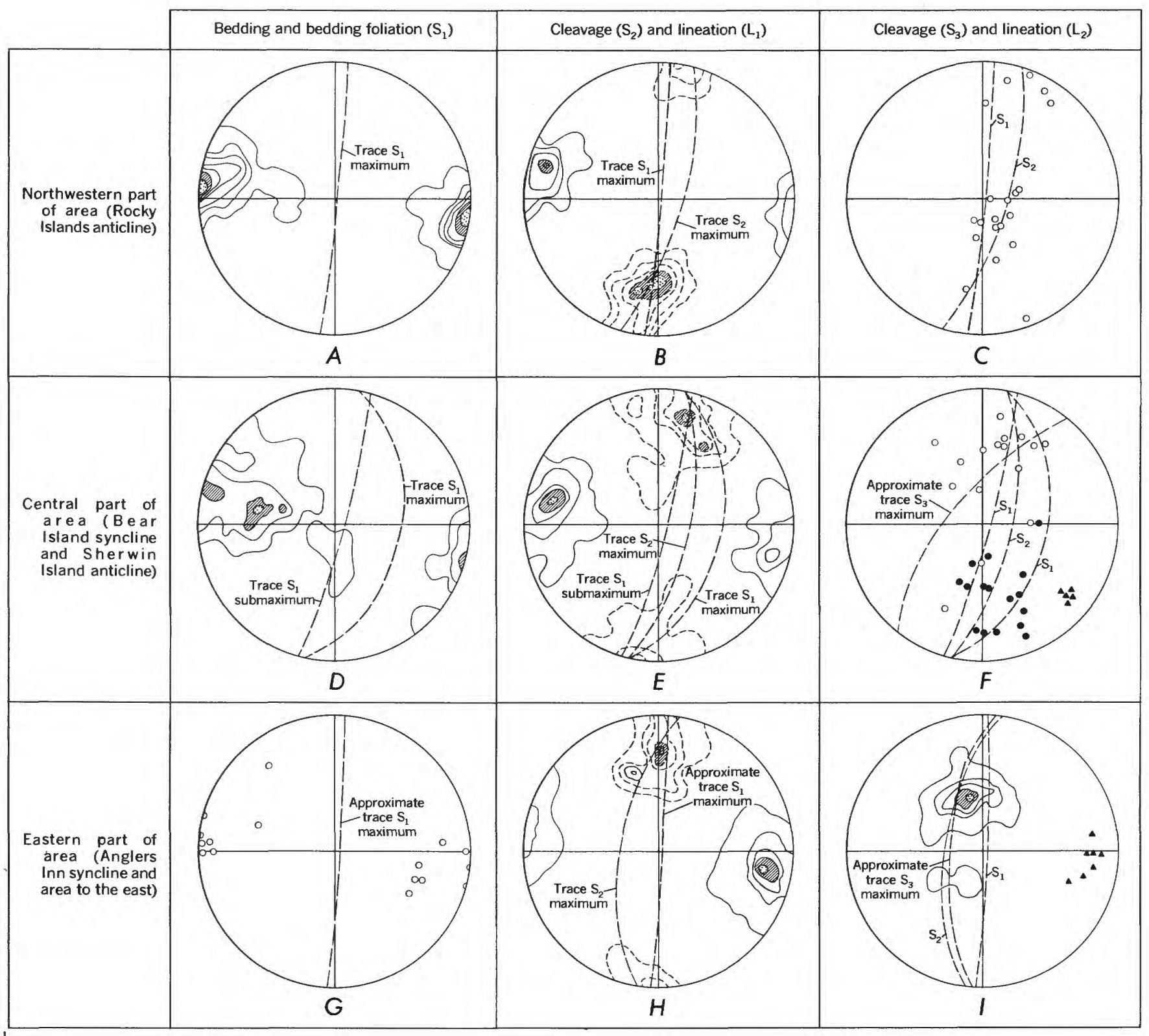

Figure 15.-Diagrams showing the orientation of structures. All diagrams are equal-area projections in the lower hemisphere with planes of projection horizontal and north at the top. Contours show percentage of points falling within 1 percent of the area of the diagram. A. 64 poles of bedding and bedding foliation, contours 1.5-5-10-15-20-25-30 percent.

$B$. 31 poles of $S_{2}$ cleavage (solid contours), contours $3-10-20-30-35$ percent; 45 L lineations (dashed contours), contours $2-5-10-$ 15-20 percent

C. 22 mineral lineations $\left(L_{2}\right)$.

D. 62 poles of bedding and bedding foliation, contours $1.5-5-10-15$ percent.

$E$. 76 poles of $S_{2}$ cleavage (solid contours), contours $1-5-10-15-20$ percent; $67 L_{1}$ lineations (dashed contours), contours 1-5-1015-20 percent.

F. 16 mineral lineations $\left(L_{2}\right)$ in amphibolite (solid circles); 16 mineral lineations $\left(L_{2}\right)$ in schist and quartzite (open circles); 5 poles of $S_{3}$ cleavage (triangles).

G. 14 poles of bedding and bedding follation.

$H$. 89 poles of $S_{2}$ cleavage (solid contours), contours 1-10-15-20-25 percent; $40 L_{1}$ lineations (dashed contours), contours 2.5-5-10$15-20$ percent.

I. 40 mineral lineations $\left(L_{2}\right)$, contours 2-5-10-15-20-25 percent; 7 poles of $S_{3}$ cleavage (triangles). 
structural diagrams have been prepared for the northwestern, central, and eastern parts of the area.

\section{$s_{1}$}

Attitudes of bedding and bedding foliation $\left(S_{1}\right)$ are shown in diagrams $A, D$, and $G$ (fig. 15). $S_{1}$ poles fall along partial girdles with axes trending a few degrees east of north, parallel to the trend of the axes of the large folds inferred from mapping. The $S_{1}$ girdle is most complete in the central part of the area; in the northwestern and eastern parts most $S_{1}$ planes are nearly vertical, and the $S_{1}$ diagrams show single high maxima on the partial girdles.

\section{$S_{2}$ AND L}

Orientations of $S_{2}$ cleavage and $L_{1}$ lineation are shown in diagrams $B, E$, and $H$ (fig. 15). $S_{2}$ poles cluster around single maxima which lie on the $S_{1}$ partial girdles. $S_{2}$ planes dip steeply east in the northwestern part of the area, steeply east or vertically in the central part, and steeply west in the eastern part. $L_{1}$ lineations cluster around maxima near the intersection of $S_{1}$ and $S_{2}$ at the poles of the $S_{1}$ girdles, indicating that most $L_{1}$ lineations are $B$-lineations parallel to axes of $B$-folds. Submaxima in the $L_{1}$ orientations in the central and eastern part of the area (diagrams $E$ and $H$, fig. 15) mark crenulations and axes of $B^{\prime}$-folds parallel to intersections of $S_{1}$ and $S_{2}$ with $S_{3}$.

The diagrams show that the $S_{1}$ girdles, the $S_{2}$ cleavage, and most of the $L_{1}$ lineations are related to the formation of the observed $B$-folds and that the $B$-folds observed in outcrop have the same orientation and symmetry as the larger folds inferred from mapping.

\section{$\mathbf{S}_{8}$ AND $\mathbf{L}_{2}$}

Orientations of $S_{3}$ cleavage planes and $L_{2}$ mineral lineations are shown in diagrams $C, F$. and $I$, figure 15 . Poles of $S_{3}$ planes are shown only where they could be clearly distinguished from $S_{2}$. Most $L_{2}$ lineations lie on $S_{1}$ or $S_{2}$ planes transverse to $L_{1}$ lineations, but a few in the northwestern and central parts of the area are nearly parallel to $L$ and may be related to it. Mineral lineations marked by alinement of amphibole prisms in amphibolite in the central part of the area display a different orientation than mineral lineations in the enclosing rocks (diagram $F$, fig. 15).

The geometrical interpretation of the orientation of the various $L_{2}$ lineations is unclear, probably in part because of failure to distinguish different types of $L_{2}$ lineations in the field. The orientation pattern of most of the $L_{2}$ lineations and $S_{3}$ cleavages does not fit into the symmetry pattern of the $B$-folds, and their field relations indicate that these structures were formed later.

The strong development of $L_{2}$ lineation in the lowgrade retrogressively metamorphosed rocks in the eastern part of the area (diagram $I$, fig. 15) and the absence of fold axes parallel to the $L_{2}$ lineation suggest that the lineations are in the $a$ fabric direction with respect to the second deformation.

Mineral lineations are not as conspicuous in the medium- and high-grade rocks in the central and northwestern parts of the area, where retrogressive metamorphism has been less thorough. In these areas $L_{2}$ lineations generally fall into two main groups, one set plunging gently or moderately north or northeast and the other set plunging gently to steeply southeast or south (diagrams $C$ and $F$, fig. 15). A few lie on $S_{3}$ planes and plunge north or northeast, parallel to $L_{2}$ lineation in the eastern part of the area. Many of the north- or northeast-plunging lineations lie near the intersection of $S_{3}$ cleavage with $S_{1}$ and $S_{2}$ (diagram $F$, fig. 15) and are probably related to these intersections. A few of the gently plunging $L_{2}$ lineations are subparallel to axes of $B$-folds and may have formed during the first deformation. The $L_{2}$ lineations that plunge steeply or moderately south, southeast, or east are not parallel to any observed fold axes or $S$-plane intersections and may mark local movement direction along reactivated $S_{1}$ and $S_{2}$ planes during the second deformation.

\section{RELATION OF STRUCTURAL EPISODES TO METAMORPHIC EVENTS}

The early stages of the first regional metamorphism were apparently synchronous with the formation of $B$-folds, but the occurrence of rocks of the highest metamorphic grade in the Bear Island syncline, and the relations locally observed between sillimanite and kyanite and micas growing along the $S_{2}$ cleavage planes indicate that the metamorphism reached its climax somewhat after the major folding. The correspondence of the area of migmatitic rocks with the area of occurrence of sillimanite suggests that the migmatization took place during the peak of the regional metamorphism, while relict structures in the migmatite show that the structural pattern of the folding had been imposed on the rocks prior to migmatization.

The only rocks that do not display the structural patterns imposed during the formation of the $B$-folds are the locally mobilized migmatites, the discordant granitic rocks, and the pegmatites and veins associated with them. The granitic rocks truncate the $S_{2}$ cleavage and contain rotated inclusions displaying folds and $S_{2}$ cleav- 
age in aberrant attitudes (fig. 11), indicating that the granitic rocks were emplaced after the folding.

Most $S_{3}$ cleavage planes and mineral lineations $\left(L_{2}\right)$ are not symmetrical with respect to the $B$ fabric axes. Their distribution and character suggest that they formed during retrogressive metamorphism of the medium- and high-grade rocks.

The $L_{2}$ lineation commonly lies on $S_{2}$ cleavage planes, which were formed during the earlier deformation. This suggests that the later deformation occurred along the previously formed $S_{2}$ planes and that only locally were new $S_{3}$ cleavage planes developed transverse to the old $S_{2}$ planes. Additional evidence was seen where thin granitic dikes cut the $S_{2}$ cleavage planes but are themselves offset along planes parallel or subparallel to the $S_{2}$ planes, showing that renewed movement has occurred along the $S_{2}$ planes after emplacement of the dikes (fig. 9B).

\section{SUMMARY OF STRUCTURAL AND METAMORPHIC HISTORY}

Table 1 summarizes the inferred structural and metamorphic history of the area. The general sequence of metamorphic events, as indicated in table 1, is fairly well established by the present study, but the geologic and absolute chronologies are unknown. Inasmuch as structural evidence indicates that the emplacement of the granitic rocks occurred shortly after the climax of regional metamorphism, the age of the granitic rocks may furnish the key to the metamorphic chronology of the area. A single determination by the Larsen method of the age of zircon from one of the discordant granitic bodies on Bear Island (Jaffe and others, 1959, specimen no. 272 ) gives 568 million years, but there is some question as to the significance of this figure, both because of the heterogeneity of the zircon suite in the sample (Jaffe, oral communication, 1958) and because of uncertainties in the laboratory procedures. If the age is correct the climax of regional metamorphism in the area occurred probably during Early Cambrian time and the schist and quartzite (Wissahickon(?) Formation) are Precambrian.

Recent radiometric age determinations of minerals from rocks near Baltimore (Tilton and others, 1959) have shown that pegmatites (and probably granites) were emplaced in the Wissahickon(?) Formation in that area about 450 million years ago and that there is evidence of a later metamorphic event about 300 million years ago. It is possible that the period of pegmatite injection in the Baltimore area may be synchronous with the period of emplacement of granitic rocks in the Potomac Gorge, and that the later event may be synchronous with the hydrothermal alteration and retrogressive metamorphism in the rocks along the Potomac River.

Our study has established the presence of partially retrogressively metamorphosed rocks of medium and high metamorphic grade among the rocks mapped by Cloos and Cooke (1953) as being of low metamorphic grade. In the area studied the boundary between the medium- and high-grade rocks and thoroughly retrogressively metamorphosed rocks of low metamorphic grade to the east falls at the pronounced change from predominantly northeast lineation trends to predominantly west or northwest lineation trends, which was recognized by Cloos (1946, pl. 10) and which is conspicuous on the geologic map of Montgomery County (Cloos and Cooke, 1953). Our study indicates that the northeast-trending lineations are $B$-lineations formed during medium- and high-grade regional metamorphism, and that the west- or northwest-plunging lineations are probably mostly $a$-lineations formed during the later retrogressive metamorphism.

Detailed mapping of adjoining areas, especially of the exposures along the Potomac River northwest and southeast of the area studied, is needed to determine the relation of the medium- and high-grade rocks we have described to rocks of apparently low metamorphic grade to the west and to rocks of apparently medium or high metamorphic grade to the east mapped by Cloos and Cooke (1953). Similar detailed mapping along the Patuxent River would assist in establishing these relations, which are critical in the interpretation of the structural and metamorphic history of this part of the Piedmont.

Radiometric age determinations on minerals from the rocks in the area studied should make it possible to establish the date of the climax of the first regional metamorphism and granitic intrusion in this part of the Piedmont and might indicate the age of other metamorphic and structural events.

Petrographic studies might further elucidate the relations between the various metamorphic and structural events, and more detailed geochemical and petrologic studies might confirm or refute our inferences as to the origin and mode of emplacement of the granitic rocks and the origin of the chlorite-muscovite gneiss.

We hope that this discussion will draw attention to the many questions which remain unresolved and may encourage others to undertake studies in this area. 
TABLE 1.-Summary of structural and metamorphic history

STRUCTURAL EPISODES
Northwest part of area
Central part of area

East part of area

METAMORPHIC EPISODES

Emplacement of large quartz veins

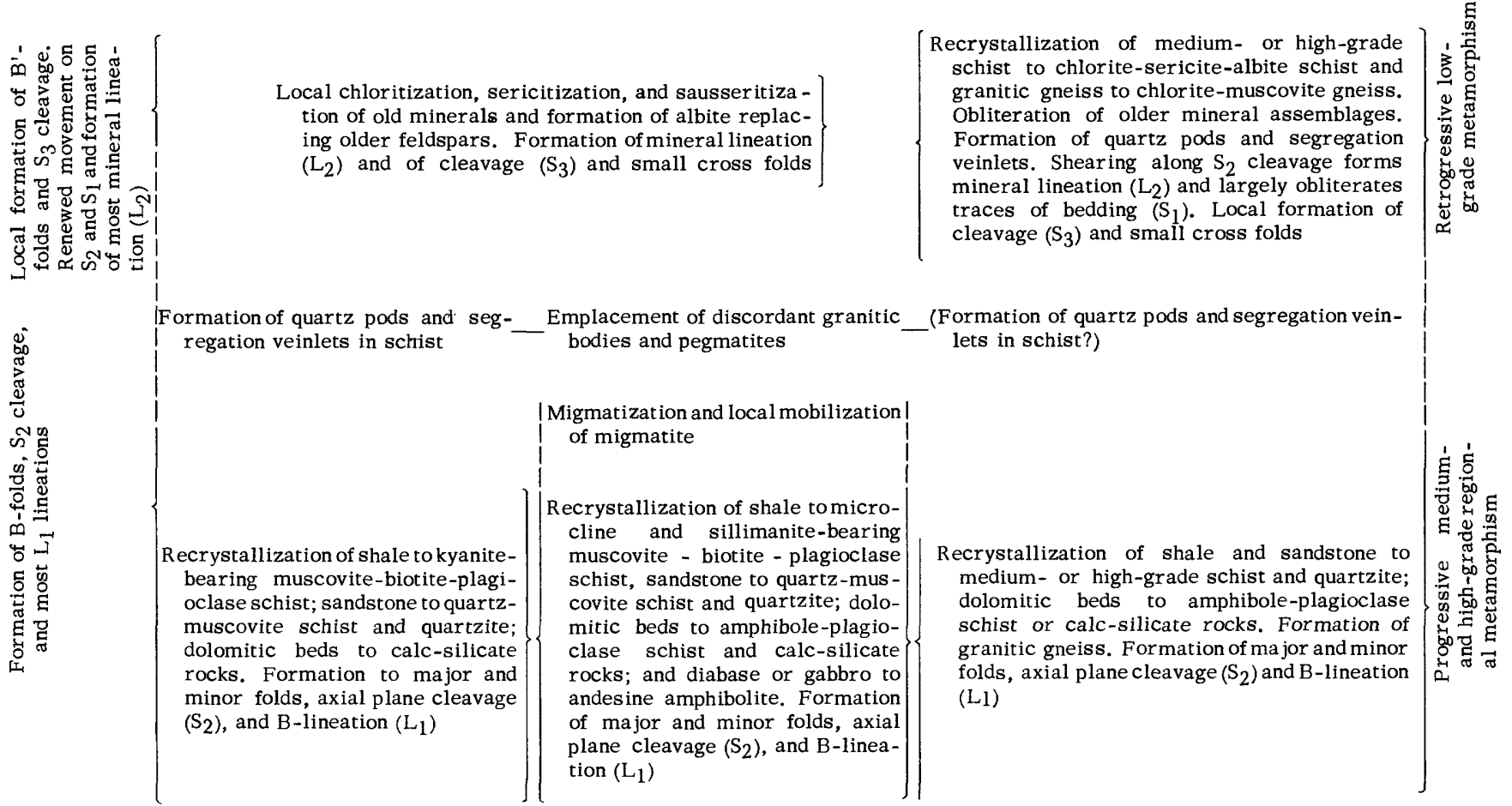

Intrusion of sills of diabase or gabbro; (formation of cordierite and andalusite in enclosing rocks?)

Deposition of shale interbedded with arkosic sandstone, locally with thin dolomitic beds

\section{REFERENCES CITED}

Bennison, A. P., and Milton, Charles, 1954, Preliminary geologic map of the Fairfax, Va., and parts of the Seneca, Md.-Va., quadrangles : U.S. Geol. Survey open-file report.

Chapman, R. W., 1942, "Pseudomigmatite" in the Piedmont of Maryland: 'Geol. Soc. America Bull., v. 53, p. 1299-1330.

Cloos, Ernst, 1946, Lineation, a critical review and annotated bibliography: Geol. Soc. America Mem. 18.

Cloos, Ernst, and Anderson, J. L., 1950, The geology of Bear Island, Potomac River, Maryland : The Johns Hopkins Univ. Studies in Geology, no. 16, pt. 2.

Cloos, Ernst, and Broedel, C. H., 1940, Geologic map of Howard and adjacent parts of Montgomery and Baltimore Counties [Md.] : Maryland Geol. Survey.

Cloos, Ernst, and Cooke, C. W., 1953, Geologic map of Montgomery County and the District of Columbia: Maryland Dept. Geology, Mines and Water Resources.

Darton, N. H., and Keith, Arthur, 1901, Geology of the Washington quadrangles: U.S. Geol. Survey Geol. Atlas, Folio 70.

Grout, F. F., 1941, Formation of igneous-looking rocks by metasomatism; a critical review and suggested research : Geol. Soc. America Bull., v. 52, p. 1525-1576.
Ingalls, Edgar, 1961 (?), The discovery of gold at Great Falls, Maryland: $17 \mathrm{p}$. (no publisher or date indicated).

Jaffe, Howard, and others, 1959, Lead-alpha age determinations of accessory minerals of igneous rocks (1953-1957): U.S. Geol.'Survey Bull.'1097-B, p. 65-148.

Jonas, Anna, 1928, Geologic map of Carroll County, Maryland: Maryland Geol. Survey.

Lonsdale, J. T., 1927, Geology of the gold-pyrite belt of the northeastern Piedmont, Virginia: Virginia Geol. Survey Bull. 30, 110 p.

Stose, Anna, and Stase, G. W., 1946, Geology of Carroll and Frederick Counties [Md.] : Maryland Dept. Geology, Mines and Water Resources, Carroll and Frederick Counties Rept.

Tilton, G. R., and others, 1959, Ages of rocks and minerals, in Ann. Rept. of the Director of the Geophys. Lab. (1958-59) : p. 170-178.

Ulke, Titus, 1939, Gold mining, past and present, near Washington, D.C. : Rocks and Minerals, v. 14, p. 299-305.

Vokes, H. E., 1957, Geography and geology of Maryland: Maryland Dept. Geology, Mines and Water Resources Bull. 19, $42 \mathrm{p}$. 


\section{Shorter Contributions to General Geology, 1961}

GEOLOGICAL SURVEY PROFESIONAL PAPER 414

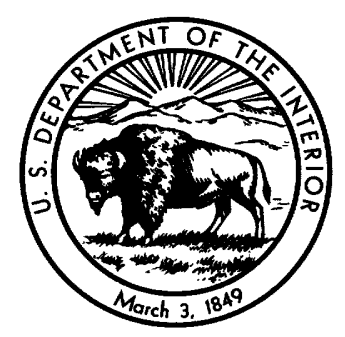

UNITED STATES GOVERNMENT PRINTING OFFICE, WASHINGTON : 1963 


\section{UNITED STATES DEPARTMENT OF THE INTERIOR}

STEWART L. UDALL, Secretary

\section{GEOLOGICAL SURVEY}

Thomas B. Nolan, Director 


\section{CONTENTS}

[The letters in parentheses designate separately published chapters]

(A) Interpretation of the composition and a classification of the chlorites, by Margaret D. Foster.

(B) Mohr's theory of strength and Prandtl's compressed cell in relation to vertical tectonics, by S. P. Kanizay.

(C) Some observations on the hydrochemistry and sedimentation of the Chamberlin Glacier area, Alaska, by F. H. Rainwater and H. P. Guy.

(D) The Sierra Nevada batholith-a synthesis of recent work across the central part, by Paul C. Bateman, Lorin D. Clark, N. King Huber, James G. Moore, and C. Dean Rhinehart.

(E) Algebraic and graphic methods for evaluating discordant lead-isotope ages, by L. R. Stieff, T. W. Stern, and R. N. Eicher.

(F) Geology of the Fort Peck area, Garfield, McCone, and Valley Counties, Montana, by Fred S. Jensen and Helen D. Varnes.

(G) Redescription of three species of corals from the Lockport dolomite in New York, by William A. Oliver, Jr.

(H) Crystalline rocks of the Potomac River Gorge near Washington, D.C., by John C. Reed, Jr., and Janice Jolly. 
